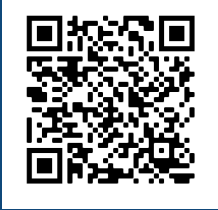

Keywords:

Bahia rosewood

In vitro cultivation

Disinfecting agents

Sodium hypochlorite toxicity

Culture media

Glutamine

Historic:

Received 12/01/2020

Accepted 08/05/2020

+Correspondence: simoes.ingridh@gmail.com
Maricélia Moreira dos Santos ${ }^{\mathrm{la}}$, Luis Filipe Cabral Cezario ${ }^{\mathrm{lb}}$, Ingridh Medeiros Simões ${ }^{\mathrm{lc}+}$, Julcinara Oliveira Baptista ${ }^{2 a}$, Caroline Palacio de Araujo ${ }^{\prime d}$, Tamyris de Mellole, Hernesise Mayard'f, Elzimar de Oliveira Gonçalves'g, Milene Miranda Praça Fontes ${ }^{2 b}$, Edilson Romais Schmildt ${ }^{3 \mathrm{a}}$, José Carlos Lopes ${ }^{2 c}$, Marcos Vinicius Winckler Caldeira ${ }^{\text {th }}$, Rodrigo Sobreira Alexandreli

\section{DISINFECTION PROTOCOL AND IN VITRO GERMINATION OF SEEDS OF Dalbergia nigra}

SANTOS, M.M.; CEZARIO, L. F. C.; SIMÕES, I. M.; BAPTISTA, J. O.; ARAUJO, C. P.; MELLO, T.; MAYARD, H.; GONÇALVES, E. O.; FONTES, M. M. P.; SCHMILDT, E.R.; LOPES, J. C.; CALDEIRA, M. V. W.; ALEXANDRE, R. S. Disinfection protocol and in vitro germination of seeds of Dalbergia nigra. CERNE, v. 26, n. 2, p.238-246, 2020.

\section{HIGHLIGHTS}

$\mathrm{NaOCl}$ (I4 min) is indicated for the disinfestation of seeds of bahia rosewood.

$\mathrm{NaOCl}$ exhibited toxicity in the lettuce seed model.

The WPM medium is more suitable than the MS.

In the medium WPM, the use of glutamine is suggested.

\section{ABSTRACT}

The Atlantic Forest is a biome that has suffered anthropic actions, such as the extraction of hardwood, which can lead to the extinction of endemic species of great economic and ecological value, such as Dalbergia nigra. In this perspective, large-scale multiplication studies are necessary to contribute to the conservation of this species. The objective of this work was to establish a protocol for the in vitro production of axenic seedlings of $D$. nigra. Four experiments were performed: I. Immersion times in $\mathrm{NaOCl}$. II. Disinfecting agents in seed germination of $\mathrm{D}$. nigra. III. $\mathrm{NaOCl}$ toxicity in seeds of the model species Lactuca sativa L. IV. Culture media and glutamine in the germination and initial growth of D. nigra. All experiments were arranged in a completely randomized design. For a better disinfestation and less harmful effects to the seedlings, it is recommended that the seeds be treated with $70 \%$ alcohol (I min) and $\mathrm{NaOCl}(14 \mathrm{~min})$. $\mathrm{NaOCl}$ has a high phytotoxic, cytotoxic, and genotoxic effect, and its mechanism of action in the L. sativa cell cycle is clastogenic and aneugenic, suggesting the formation of abnormal seedlings in $D$. nigra. The WPM medium and its supplementation with glutamine $\left(0.75 \mathrm{mg} \cdot \mathrm{L}^{-1}\right)$ are recommended.
' Federal University of Espirito Santo, Jerônimo Monteiro, Espírito Santo, Brazil - ORCID: 0000-0003-0956-696X

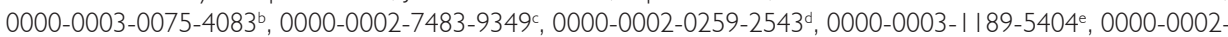
7572-5554f, 0000-000 I-7675-24938, 0000-0003-469I-989 I, 0000-0002-5248-6773

2 Federal University of Espirito Santo, Alegre, Espírito Santo, Brazil- ORCID: 0000-0003-349 I-5498a, 0000-000 I7738-951 8, $0000-0002-4880-0547^{c}$

${ }^{3}$ Federal University of Espirito Santo, São Mateus, Espírito Santo, Brazil - ORCID: 0000-0002-3457-7997ª 


\section{INTRODUCTION}

Dalbergia nigra (Vell.) Fr. All. Ex Benth. (Papilionoideae) is an endemic species to the Atlantic Forest, popularly known as Bahia rosewood (Lorenzi, 2016). Due to the intense exploitation of its timber resources, along with anthropogenic actions on the forest, attacks by pests (Troezon championi Lima) on seeds, and predators (Sylvilagus brasiliensis Linnaeus) on seedlings, its population has been disappearing and is now on the Red List of Threatened Species (Brasil, 20I4; Leite et al., 20I4).

In vitro germination is an alternative for the propagation of species with difficulty for seminiferous multiplication under natural conditions, allowing largescale production in a shorter period of time and space, besides obtaining seedlings with high phytosanitary quality (Franceschi et al., 2019). One of the major problems faced in in vitro propagation is the explant disinfestation and its establishment free of contaminants, which may be either of exogenous (fungus) origin, limiting the tissue surface, or endogenous (bacteria), localized within the organism (Karmakar et al., 2019; Mendy et al., 2019), and making multiplication unfeasible.

Disinfestation protocols vary between the species and type of explant used, which are exposed to disinfecting agents with their respective exposure times (Santos et al., 2019). Woody species present greater difficulty for in vitro establishment due to the greater contamination of explants (Sarmast, 2018).

Given the great benefits of in vitro propagation and the need for more detailed studies on the behavior of bahia rosewood, in this condition, this work aimed to establish a protocol for the in vitro production of axenic seedlings of Dalbergia nigra.

\section{MATERIAL AND METHODS}

Mature seeds of Dalbergia nigra harvested from matrices located in Viçosa, Minas Gerais (2045'35. I"S, $42^{\circ} 52^{\prime} 06$. I' $\mathrm{W}$ ) and obtained with the Society of Forest Investigations (SIF) of the Federal University of Viçosa (UFV) were used in the experiment. The SIF is registered in the Ministry of Agriculture, Livestock, and Supply.

Experiment I: Disinfestation and in vitro germination of $D$. nigra seeds with different $\mathrm{NaOCl}$ immersion times.

In a laminar flow cabinet, the seeds were immersed in alcohol (70\%) for one minute, and then in a commercial solution (Candura ${ }^{\circledR}$ ) of sodium hypochlorite $(\mathrm{NaOCl})(2.0-2.5 \%$ active chlorine), in which the immersion times of $0 ; 5 ; 10 ; 15 ; 20$, and 25 min constituted the treatments. Afterward, a triple wash with distilled and autoclaved water was performed after the use of each disinfecting agent. The experiment was conducted in a completely randomized design with four replications of 25 seeds.

One seed was placed per test tube containing $10 \mathrm{~mL}$ of the Sigma-Aldrich ${ }^{\circledR}$ Woody Plant Medium (WPM) culture medium (Lloyd and McCown, 1980), supplemented with sucrose (3\%, Dinamic $\left.{ }^{\circledR}\right)$, myo-inositol (100 mg. $\mathrm{L}^{-1}$, SigmaAldrich $\left.{ }^{\circledR}\right), \mathrm{pH}$ adjusted to $5.7 \pm 0.1$, and solidified with agar (7 g. $\mathrm{L}^{-1}, \mathrm{Kasvi}\left({ }^{\circledR}\right)$, being sterilized by autoclaving for $20 \mathrm{~min}$ at $121^{\circ} \mathrm{C}$ and $\mathrm{I}$ atm pressure. The in vitro germination experiments were kept in a growth room under a $50 \mu \mathrm{mol} \mathrm{m}-2 \mathrm{~s}-\mathrm{I}$ photosynthetic photon flux density obtained by white LED lamps, in a 16-hour photoperiod and temperature of $27 \pm 2{ }^{\circ} \mathrm{C}$.

The following characteristics were evaluated for 30 days: contamination (\%), germination (\%), nongerminated seeds $(\%)$, germination speed index, mean germination time (days), normal seedlings (\%), abnormal seedlings (\%), total length $(\mathrm{cm})$, number of leaves, collar diameter $(\mathrm{mm})$, and total dry mass of seedlings $(\mathrm{mg})$.

Germination (\%) was conducted with four replications of 25 seeds for each treatment. The germinated seeds were counted daily for 30 days. Germination was characterized by the emission of the primary root with a length greater than or equal to two millimeters (Brasil, 2009). The results were expressed as the percentage of germination.

The germination speed index (GSI) was determined concomitantly with the germination test, daily computing the number of seeds that showed protrusion of the primary root equal to or greater than $2 \mathrm{~mm}$ (Maguire, 1962), being counted until the 30th day. The GSI was calculated by summing the number of seeds germinated at each day and dividing this value by the number of days elapsed between sowing and germination: $\mathrm{GSI}=(\mathrm{GI} / \mathrm{NI})+(\mathrm{G} 2 / \mathrm{N} 2)+(\mathrm{G} 3 /$ $\mathrm{N} 3)+\ldots+(\mathrm{Gn} / \mathrm{Nn})$, where: $\mathrm{GSI}=$ germination speed index; GI, G2, G3, ..., Gn = number of germinated seeds computed at the first, second, third, and last count; NI, $\mathrm{N} 2, \mathrm{~N} 3, \ldots, \mathrm{Nn}=$ number of days from sowing to the first, second, third, and last count.

The equation by Laboriau (1983) was used for the determination of the mean germination time: (MGT) MGT $=\left(\sum\right.$ niti $) / \Sigma$ ni, in which, ni $=$ number of seeds germinated per day; $\mathrm{ti}=$ incubation time (days).

The percentage of normal seedlings was calculated considering the seedlings with all formed structures (root, hypocotyl, and cotyledons) in relation to the germination percentage (seedlings with primary root protrusion) at 30 days after sowing, according to Brazil (2009). Were considered as abnormal seedlings all those that did not follow the above-mentioned normality pattern, such as the rosette shape of the shoot part. 
The data were subjected to analysis of variance and the means were compared through regression analysis $(\mathrm{p}<0.05)($ Cruz, 2016).

Experiment II: Disinfectants in the establishment and in vitro germination of seeds of $D$. nigra.

The seeds were immersed in alcohol (70\%) in a laminar flow cabinet for one minute, as well as in the disinfectant agents, according to the defined treatments.

In order to enhance the number of normal seedlings and reduce the high percentage of contamination, the disinfestation experiment II was performed with the inclusion of hydrogen peroxide $\left(\mathrm{H}_{2} \mathrm{O}_{2}\right)$, Captan ${ }^{\circledR}$ fungicide, and Kasumin ${ }^{\circledR}$ bactericide. $\mathrm{NaOCl}$ ( 14 min) was selected as one of the treatments to be used, as it presented the highest percentage of normal seedlings in experiment $\mathrm{I}$.

The treatments consisted of different combinations of disinfecting agents: Candura ${ }^{\circledR}$ commercial $\mathrm{NaOCl}$ (2.0- $2.5 \%$ active chlorine); Alphatec ${ }^{\circledR}$ hydrogen peroxide $\left(\mathrm{H}_{2} \mathrm{O}_{2}\right)$; Captan SC Adama ${ }^{\circledR}$ fungicide, and the Kasumin Arysta LifeScience ${ }^{\circledR}$ bactericide, as follows: $\mathrm{TI}-\mathrm{NaOCl}$ 2.5\% (14 min); T2 - Captan 0.5\% (5 min) + Kasumin I $\mathrm{mL} . \mathrm{L}^{-1}$ (10 min); T3 - Captan 0.5\% (5 min) + Kasumin I $\mathrm{mL} . \mathrm{L}^{-1}$ ( $\left.10 \mathrm{~min}\right)$ with residue; T4 - $\mathrm{H}_{2} \mathrm{O}_{2} 10 \% \mathrm{v.v}-\mathrm{I}(5 \mathrm{~min})$; T5 - $\mathrm{H}_{2} \mathrm{O}_{2} 20 \%$ v.v-I (5 min); T6 - NaOCl 2.5\% (I4 min) $+\mathrm{H}_{2} \mathrm{O}_{2} 10 \%$ v.v-I (5 min); $\mathrm{T} 7-\mathrm{NaOCl} 2.5 \%(14 \mathrm{~min})+$ $\mathrm{H}_{2} \mathrm{O}_{2} 20 \%$ v.v-I (5 min). A triple wash was then performed with distilled and autoclaved water, and the experiment was performed in a completely randomized design, with seven treatments and four replications of 10 seeds.

One seed was inserted into each test tube, which contained $10 \mathrm{~mL}$ of the WPM culture medium (Lloyd and McCown, 1980) supplemented with sucrose (30 g.L-1, Dinamic $\AA$ ), myo-inositol (100 mg. $\mathrm{L}^{-1}$, Sigma-Aldrich $\left.\AA\right)$, $\mathrm{pH}$ adjusted to $5.7 \pm 0.1$, and solidified with agar $\left(5.5 \mathrm{~g} . \mathrm{L}^{-1}\right.$, Kasvi $\left.{ }^{\circledR}\right)$, autoclaved for $20 \mathrm{~min}$ at $\mathrm{I} 2 \mathrm{I}^{\circ} \mathrm{C}$ and a pressure of $\mathrm{I}$ atm.

The following characteristics were evaluated for 30 days: contamination (\%), germination (\%), non-germinated seeds (\%), germination speed index, mean germination time (days), normal seedlings (\%), abnormal seedlings (\%), total length $(\mathrm{cm})$, number of leaves, collar diameter $(\mathrm{mm})$, and total dry mass of seedlings (mg). The data were subjected to analysis of variance and the means were compared by the Scott-Knott clustering test $(p<0.05)(C r u z, 2016)$.

Experiment III: Evaluation of $\mathrm{NaOCl}$ toxicity in a Lactuca sativa L. seed bioassay as a model plant.

L. sativa seeds are used for bioassays because they are highly sensitive to the environment, presenting low reserve tissues that allow them to easily absorb the compounds to which they are subjected (Andrade et al., 2010; Rodrigues et al., 2013).
Seeds of the lettuce (Lactuca sativa L.) Manteiga (Feltrin Sementes ${ }^{\circledR}$ ) were used for the toxicity test, being analyzed in a completely randomized design, with treatments corresponding to five concentrations of $\mathrm{NaOCl}(0.1 ; 0.5 ; 1.0 ; 1.5$, and $2.0 \%)$, a glyphosate herbicide solution (positive control), and distilled water (negative control), with five replications of 25 seeds.

The seeds were placed in Petri dishes with Germitest ${ }^{\circledR}$ paper moistened with $2.5 \mathrm{~mL}$ of the solution corresponding to each treatment. These were then taken to a BOD (Biochemical Oxygen Demand) germination chamber with a 12-hour photoperiod and temperature of $27 \pm 2{ }^{\circ} \mathrm{C}$. The germination and GSI were counted every eight hours over a period of 48 hours.

After 48 hours, the root length $(\mathrm{cm})$ was measured with a digital caliper. Ten seedlings from each treatment were randomly selected for fixation in a solution of methanol and acetic acid (3:I), and placed in a freezer. After I 20 hours, the shoot length $(\mathrm{cm})$ of the seedlings that remained in the Petri dishes was measured with a digital caliper.

At room temperature, the fixed seedlings were subjected to a triple distilled water wash (10 min per wash), immersed in an $\mathrm{HCl} 5 \mathrm{~N}$ solution for $18 \mathrm{~min}$, and again in distilled water for $10 \mathrm{~min}$. The mitotic index was then determined using the crush technique (Guerra and Souza, 2002).

In a microscope slide, the hood was removed to obtain the apical meristem, which was stained with $2 \%$ acetic orcein and covered by a coverslip. The slides were observed under an objective microscope lens (Nikon ${ }^{\circledR}$ BE Plan $40 x / 0.65$ ) and were accounted for by the observation of 1000 cells per treatment in interphase, prophase, metaphase, anaphase, telophase, dividing cells, mitotic index (\%), and chromosomal changes (\%).

The mitotic index was obtained by dividing the number of cells in mitosis by the total number of cells observed, multiplying by 100 . The data were subjected to analysis of variance and the means were compared by Dunnett's test $(p<0.05)($ Cruz, 2016).

Experiment IV: Culture media and glutamine in the germination and initial growth of $D$. nigra.

In a laminar flow chamber, the seeds were disinfected in alcohol (70\%) for one minute, followed by immersion in sodium hypochlorite, $\mathrm{NaOCl}(2.0-2.5 \%$ active chlorine) (SuperGlobo ${ }^{\circledR}$ ) for $14 \mathrm{~min}$. After the use of each of these disinfecting agents, the seeds were subjected to a triple wash in distilled and autoclaved water. The culture media used were the MS (Murashige and Skoog, 1962) and WPM (Lloyd and McCown, 1980), supplemented with sucrose (30 g. $\mathrm{L}^{-1}$, Dinamic $\left.{ }^{\circledR}\right)$, myoinositol (100 mg. $\mathrm{L}^{-1}$, Sigma-Aldrich $\left.{ }^{\circledR}\right)$, glutamine $(0$; $0.25 ; 0.5$, and $\left.0.75 \mathrm{mg} \cdot \mathrm{L}^{-1}\right)$, and solidified with agar ( 5.5 
g. $\mathrm{L}^{-1}, \mathrm{Kasvi}\left({ }^{\circledR}\right)$. The $\mathrm{pH}$ of the culture medium was adjusted to $5.7 \pm 0$. I. The culture medium was distributed in plasticcapped vials and sterilized by autoclaving for $20 \mathrm{~min}$ at a temperature of $121^{\circ} \mathrm{C}$ and a pressure of $\mathrm{I}$ atm.

The experiment was arranged in a completely randomized design, in a $2 \times 4$ factorial scheme (culture media: MS and WPM $x$ Glutamine: 0; 0.25; 0.5, and 0.75 mg.L-I), totaling eight treatments with four replications of 25 seeds each. The characteristics analyzed were: contamination (\%); germination (\%); non-germinated seed (\%); germination speed index; mean germination time (days); normal seedlings; abnormal seedlings (\%); non-developed seedling (\%); number of leaves; collar diameter $(\mathrm{mm})$; shoot length $(\mathrm{mm})$; root length $(\mathrm{mm})$; number of lateral roots; shoot dry mass of seedlings $(\mathrm{mg})$, root dry mass of seedlings $(\mathrm{mg})$, and total dry mass of seedlings ( $\mathrm{mg}$ ).

The data were subjected to analysis of variance and the $\mathrm{F}$ test at $5 \%$ significance for both media types and the culture media $x$ glutamine concentrations interaction. The means were analyzed by regression (Cruz, 2016).

\section{RESULTS AND DISCUSSION}

Experiment I: Disinfestation and in vitro germination of seeds of $D$. nigra with different $\mathrm{NaOCl}$ immersion times

The different immersion times in $\mathrm{NaOCl}$ showed no significant difference for the variables of contamination, germination, non-germinated seeds, GSI, MGT, abnormal seedlings, total seedling length, leaf number, collar diameter, and total seedling dry mass (Figure I).
The contamination (29.25\%) of explants at different $\mathrm{NaOCl}$ concentrations (Figure I) was 100\% bacterial. The germination percentage, regardless of the time of exposure to $\mathrm{NaOCl}$, was $52.41 \%$ (Figure I), with a mean germination time of 9.47 days (Figure I). The highest percentage of normal seedlings (4I.95\%) was obtained with 14 min of exposure to $\mathrm{NaOCl}$ (Figure I). $\mathrm{NaOCl}$ reduced contamination and, consequently, favored a higher percentage of normal seedlings of Melanoxylon brauna up to a maximum exposure time of $25 \mathrm{~min}$ (Silva et al., 20 19). In D. nigra, above I 4 min of exposure of the seeds to $\mathrm{NaOCl}$, there was a reduction in seedling normality (Figure I). The determination of this exposure time to the $\mathrm{NaOCl}$ disinfecting agent is extremely important as it helps to reduce cytotoxicities and genotoxicities. Santos et al. (2019) used a lower concentration of $\mathrm{NaOCl}$ (1\%), which was efficient for the in vitro establishment of nodal segments of Olea europaea L. 'Arbequina' and 'Koroneiki', not promoting seedling toxicity.

$\mathrm{NaOCl}$ adsorbs to the seed surface and, even after several washes with water, the residue is still capable of causing reactions with organic compounds. As the exposure time to the product increases, more residue is adsorbed by the seed, reacting with amino acids and generating a high concentration of ammonium chloride $(\mathrm{NH} 4 \mathrm{Cl})$ and carbon dioxide $\left(\mathrm{CO}_{2}\right)$ in the test tube. Furthermore, $\mathrm{NaOCl}$ hydrolysis produces hypochlorous acid $(\mathrm{HClO})$, a toxic compound that leads to cellular and photosynthetic changes, among others, negatively affecting seedling growth, which
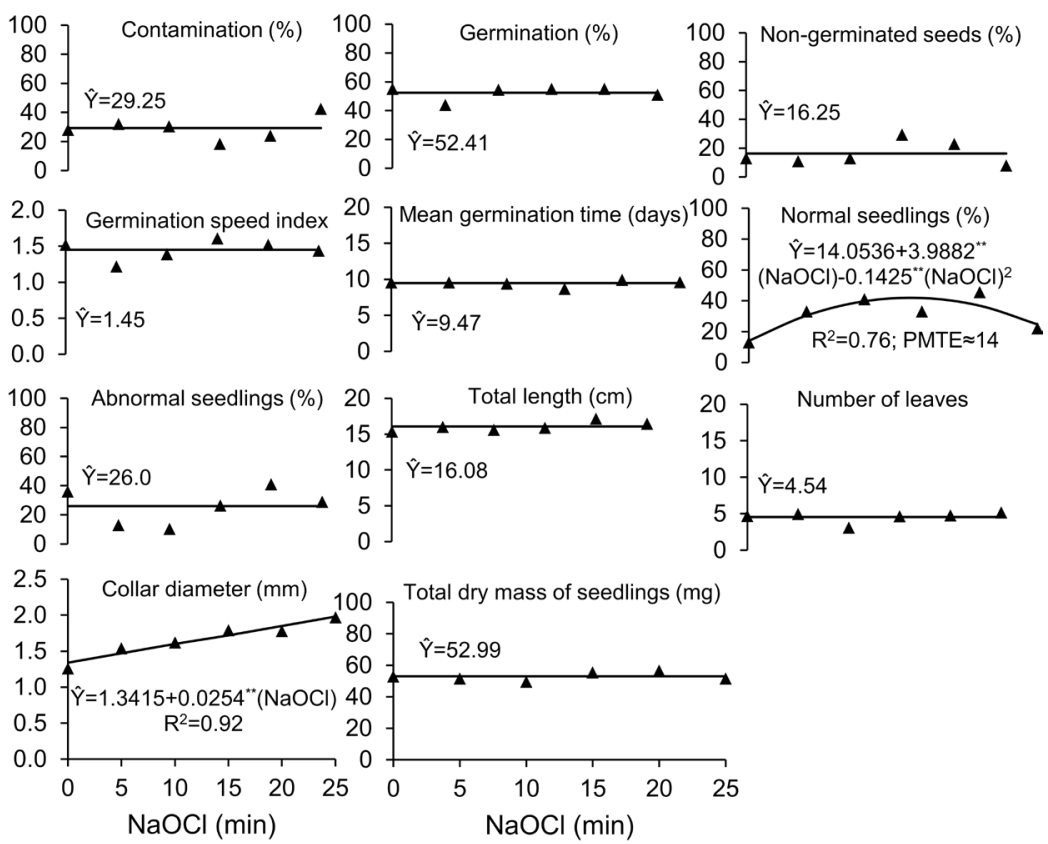

FIGURE I Characteristics evaluated in seeds and seedlings of $D$. nigra after different seed immersion times in $\mathrm{NaOCl}$. ** Significant at a $5 \%$ level of probability. Abbreviation: PMTE. Point of maximum technical efficiency. 
causes abnormal seedling formation (Abdul-Baki, 1974; Gamage et al., 2018).

With the increase in the exposure to $\mathrm{NaOCl}$, there was an increase in the diameter of the seedling collar (Figure I). This may be related to the response of the seedlings to the effect of $\mathrm{NaOCl}$, promoting a thickening of the collar, a phenomenon characterized as rusticity, mediated by stress.

Experiment II: Disinfecting agents in the establishment and in vitro germination of seeds of $D$. nigra

There was a significant difference for contamination, shoot length, shoot dry mass, root dry mass, and total dry mass of seedlings (Table I).

Although no statistical difference was observed between the treatments that provided the lowest contamination rates (TI, T2, T6, and T7), it was decided to choose TI for the disinfestation of seeds of Dalbergia nigra, aiming at a lower tissue exposure to stress and the reduction of production costs of axenic seedlings using economically viable disinfecting agents, such as alcohol and $\mathrm{NaOCl}$. Treatments $\mathrm{T} 3, \mathrm{~T} 4$, and $\mathrm{T} 5$ presented the highest percentages of contamination, having in common the absence of hypochlorite (Table I). This is an important disinfecting agent since the chlorine present in the molecule combines with proteins in the cell membranes of the microorganism, forming toxic compounds that inhibit essential enzymes for its proliferation (Donini et al., 2005). For example, the antibacterial efficiency (93\%) of the use of $\mathrm{NaOCl}(2.5 \%)$, for $30 \mathrm{~min}$, was proven in seeds of Calendula officinalis L. (Bevilacqua et al., 20I I).
In experiment II, the percentage of twinning and normal seedlings did not differ between treatments, with a mean of $77.86 \%$ ( $25.45 \%$ higher than experiment $\mathrm{I})$ and $66.07 \%$ (24.12\% higher than experiment I), respectively. It was also verified that the contamination was 3.9 times lower when compared to the experiment I, indicating that the origin of the batch has a great influence on these characteristics (Table I).

Contamination can be a hindrance in in vitro establishment, as contaminants compromise seedling growth, either by competition for nutrients or the production of phytotoxic metabolites, such as lactic and acetic acids (Monfort et al., 20I5).

The seedlings of $\mathrm{TI}$, along with treatments $\mathrm{T} 2$, T3, and T7 presented one of the highest values of SDMS (8.04 mg). Its RDMS (3I.45 mg) and TDMS (39.49 mg) did not differ statistically from most treatments, except for T4, which presented the lowest value $(20.67 \mathrm{mg})$ (Table I). The dry mass content incorporated by the seedlings is one of the main quality characteristics, which are important for acclimatization, as it indicates a greater rusticity and ability to overcome water loss, oscillations in relative humidity, temperature, and light intensity (George et al., 2008).

Experiment III: Evaluation of $\mathrm{NaOCl}$ toxicity in a Lactuca sativa L. seed bioassay as a model plant

Only in the treatment with the lowest concentration of $\mathrm{NaOCl}(0.1 \%)$ there was germination (Table 2), which evidences the presence of phytotoxicity in higher concentrations.

TABLE I Disinfestation treatments on germination, vigor, and in vitro growth of seedlings of $D$. nigra.

\begin{tabular}{|c|c|c|c|c|}
\hline TREAT & CONT (\%) & GER (\%) & NGS & GSI \\
\hline TI & $07.5 \pm 09.57 \mathrm{~b}(\mathrm{I})$ & $87.5 \pm 18.93 \mathrm{~ns}$ & $12.5 \pm 19.00 \mathrm{~ns}$ & $1.095 \pm 0.23 \mathrm{~ns}$ \\
\hline T2 & $15.0 \pm 12.91 \mathrm{~b}$ & $72.5 \pm 15.00$ & $27.5 \pm 15.00$ & $0.932 \pm 0.29$ \\
\hline T3 & $30.0 \pm 08.16 \mathrm{a}$ & $70.0 \pm 21.60$ & $30.0 \pm 22.00$ & $0.815 \pm 0.28$ \\
\hline T4 & $20.0 \pm 08.16 a$ & $87.5 \pm 05.00$ & $12.5 \pm 05.00$ & $0.870 \pm 0.16$ \\
\hline T5 & $25.0 \pm 10.00 \mathrm{a}$ & $70.0 \pm 14.14$ & $30.0 \pm 14.00$ & $0.842 \pm 0.18$ \\
\hline T6 & $12.5 \pm 05.00 \mathrm{~b}$ & $75.0 \pm 10.00$ & $25.0 \pm 10.00$ & $0.985 \pm 0.20$ \\
\hline T7 & $12.5 \pm 12.58 \mathrm{~b}$ & $82.5 \pm 12.58$ & $17.5 \pm 13.00$ & $1.220 \pm 0.13$ \\
\hline TREAT & MGT (days) & NS (\%) & $\mathrm{AS}(\%)$ & $\mathrm{SL}(\mathrm{cm})$ \\
\hline TI & $10.3 \pm 0.93 \mathrm{~ns}$ & $75.0 \pm 12.91 \mathrm{~ns}$ & $12.5 \pm 12.58 \mathrm{~ns}$ & $6.63 \pm 0.95 b$ \\
\hline T2 & $10.8 \pm 1.37$ & $65.0 \pm|2.9|$ & $07.5 \pm 09.57$ & $7.27 \pm 0.98 a$ \\
\hline T3 & $09.2 \pm 1.03$ & $47.5 \pm 22.17$ & $22.5 \pm 15.00$ & $8.33 \pm 0.95 a$ \\
\hline T4 & $11.1 \pm 1.47$ & $72.5 \pm 17.08$ & $15.0 \pm 17.32$ & $5.85 \pm 1.28 b$ \\
\hline T5 & $10.2 \pm 0.8 \mid$ & $67.5 \pm 09.77$ & $02.5 \pm 05.00$ & $6.54 \pm 0.63 b$ \\
\hline T6 & $10.3 \pm 0.72$ & $65.0 \pm 05.77$ & $10.0 \pm 14.14$ & $6.86 \pm 1.03 b$ \\
\hline $\mathrm{T} 7$ & $08.9 \pm 0.97$ & $70.0 \pm 08.16$ & $12.5 \pm 05.00$ & $7.95 \pm 0.80 \mathrm{a}$ \\
\hline TREAT & $\mathrm{RL}(\mathrm{cm})$ & SDMS (mg) & RDMS (mg) & TDMS (mg) \\
\hline TI & $2.93 \pm 0.57 \mathrm{~ns}$ & $8.04 \pm 2.01 \mathrm{la}$ & $31.45 \pm 7.57 a$ & $39.49 \pm 6.19 a$ \\
\hline T2 & $3.57 \pm 0.56$ & $8.6 \mathrm{I} \pm 2.47 \mathrm{a}$ & $27.40 \pm 4.19 a$ & $36.02 \pm 4.87 a$ \\
\hline T3 & $4.12 \pm 0.55$ & $8.78 \pm 3.38 a$ & $30.94 \pm 3.20 \mathrm{a}$ & $39.72 \pm 5.57 a$ \\
\hline T4 & $3.15 \pm 0.44$ & $5.48 \pm 1.77 b$ & $20.67 \pm 5.53 b$ & $26.16 \pm 7.00 \mathrm{~b}$ \\
\hline T5 & $3.18 \pm 0.53$ & $4.87 \pm 0.62 b$ & $30.54 \pm 3.25 a$ & $35.42 \pm 3.00 \mathrm{a}$ \\
\hline T6 & $2.99 \pm 0.36$ & $6.16 \pm 1.32 b$ & $31.60 \pm 1.26 a$ & $37.76 \pm 1.47 a$ \\
\hline $\mathrm{T} 7$ & $4.54 \pm 3.00$ & $8.44 \pm 1.19 a$ & $29.65 \pm 3.56 \mathrm{a}$ & $38.09 \pm 4.70 \mathrm{a}$ \\
\hline
\end{tabular}

(')Means followed by the same letter do not differ from each other by the Scott-Knott cluster test $(\mathrm{p}<0.05)$. ns Not significant. Note: The seeds in all treatments were initially immersed in $70 \%$ alcohol for I min. Abbreviations: TREAT. Treatments [TI. NaOCl (2.5\%) $14 \mathrm{~min}$; T2. Captan ${ }^{\circledR}(0.5 \%) 5 \mathrm{~min}+\mathrm{Kasumin}{ }^{\circledR}\left(\mathrm{I} \mathrm{mL} \cdot \mathrm{L}^{-1}\right) 10 \mathrm{~min}$ without residue; T3. T2 with residue; T4. $\mathrm{H}_{2} \mathrm{O}_{2}\left(\mathrm{I} \%\right.$ ) $5 \mathrm{~min}$; T5. $\mathrm{H}_{2} \mathrm{O}_{2}(20 \%) 5 \mathrm{~min}$. T6. $\mathrm{NaOCl}(2.5 \%) 14 \mathrm{~min}+\mathrm{H}_{2} \mathrm{O}_{2}(10 \%) 5 \mathrm{~min} ; \mathrm{T7} . \mathrm{NaOCl}(2.5 \%) 14 \mathrm{~min}+$ $\mathrm{H}_{2} \mathrm{O}_{2}(20 \%) 5$ min]. Abbreviations: CONT. Contamination; GER. Germination; NGS. Non-germinated seeds; GSI. Germination speed index; MGT. Mean germination time; NS. Normal seedlings; AS. Abnormal seedlings; SL. Shoot length; RL. Root length; SDMS. Shoot dry mass of seedlings; RDMS. Root dry mass of seedlings; TDMS. Total dry mass of seedlings. 
TABLE 2 Seed germination, seedling growth, cell division, mitotic index, and chromosomal changes of meristematic cells of $L$. sativa after immersion in different $\mathrm{NaOCl}$ concentrations

\begin{tabular}{|c|c|c|c|c|c|}
\hline TREAT & [] (\%) & GER (\%) & GSI & $\mathrm{RL}(\mathrm{cm})$ & $\mathrm{SL}(\mathrm{cm})$ \\
\hline \multirow{5}{*}{$\mathrm{NaOCl}(\%)$} & 0.1 & $84.0 \pm 12.65$ & $0.96 \pm 0.18$ & $3.99 \pm 0.19^{b}$ & $.46 \pm 0.26^{b}$ \\
\hline & 0.5 & $0.0 \pm 0.0$ & $0.0 \pm 0.0$ & $0.0 \pm 0.0$ & $0.0 \pm 0.0$ \\
\hline & 1.0 & $0.0 \pm 0.0$ & $0.0 \pm 0.0$ & $0.0 \pm 0.0$ & $0.0 \pm 0.0$ \\
\hline & 1.5 & $0.0 \pm 0.0$ & $0.0 \pm 0.0$ & $0.0 \pm 0.0$ & $0.0 \pm 0.0$ \\
\hline & 2.0 & $0.0 \pm 0.0$ & $0.0 \pm 0.0$ & $0.0 \pm 0.0$ & $0.0 \pm 0.0$ \\
\hline Water & - & $98.4 \pm 2.19^{a(1)}$ & $1.42 \pm 0.23^{\mathrm{a}}$ & $8.69 \pm 0.34^{a}$ & $4.63 \pm 1.05^{a}$ \\
\hline Glyphosate & 0.01 & $97.6 \pm 2.19^{b}$ & $1.38 \pm 0.09^{b}$ & $4.25 \pm 0.39^{b}$ & $1.37 \pm 0.23^{b}$ \\
\hline TREAT & [] (\%) & IC & $\mathrm{PC}$ & $M C$ & $\mathrm{AC}$ \\
\hline \multirow{5}{*}{$\mathrm{NaOCl}(\%)$} & 0.1 & $954.0 \pm 12.59$ & $21.2 \pm 3.90$ & $14.2 \pm 6.38^{\mathrm{a}}$ & $9.4 \pm 3.91$ \\
\hline & 0.5 & $0.0 \pm 0.0$ & $0.0 \pm 0.0^{\mathrm{b}}$ & $0.0 \pm 0.0^{\mathrm{b}}$ & $0.0 \pm 0.0^{b}$ \\
\hline & 1.0 & $0.0 \pm 0.0$ & $0.0 \pm 0.0^{\mathrm{b}}$ & $0.0 \pm 0.0^{\mathrm{b}}$ & $0.0 \pm 0.0^{\mathrm{b}}$ \\
\hline & 1.5 & $0.0 \pm 0.0$ & $0.0 \pm 0.0^{b}$ & $0.0 \pm 0.0^{b}$ & $0.0 \pm 0.0^{b}$ \\
\hline & 2.0 & $0.0 \pm 0.0$ & $0.0 \pm 0.0^{\mathrm{b}}$ & $0.0 \pm 0.0^{\mathrm{b}}$ & $0.0 \pm 0.0^{\mathrm{b}}$ \\
\hline Water & - & $918.0 \pm 8.97^{\mathrm{a}}$ & $32.0 \pm 11.42^{\mathrm{a}}$ & $22.0 \pm 9.67^{\mathrm{a}}$ & $23.2 \pm 6.6 \mathrm{I}^{\mathrm{a}}$ \\
\hline Glyphosate & 0.01 & $996.0 \pm 1.22^{\mathrm{b}}$ & $2.4 \pm 1.14^{b}$ & $0.6 \pm 0.90^{\mathrm{b}}$ & $1.0 \pm 0.7 \mathrm{I}^{\mathrm{b}}$ \\
\hline TREAT & [] (\%) & $\mathrm{TC}$ & $\mathrm{DC}$ & $\mathrm{MI}(\%)$ & CC (\%) \\
\hline \multirow{5}{*}{$\mathrm{NaOCl}(\%)$} & 0.1 & $1.2 \pm 0.84$ & $46.0 \pm 12.59$ & $4.6 \pm 1.26$ & $7.2 \pm 4.09$ \\
\hline & 0.5 & $0.0 \pm 0.0^{b}$ & $0.0 \pm 0.0 b$ & $0.0 \pm 0.0^{b}$ & $0.0 \pm 0.0^{\mathrm{ab}}$ \\
\hline & 1.0 & $0.0 \pm 0.0 b$ & $0.0 \pm 0.0^{\mathrm{b}}$ & $0.0 \pm 0.0^{b}$ & $0.0 \pm 0.0 \mathrm{ab}$ \\
\hline & 1.5 & $0.0 \pm 0.0^{b}$ & $0.0 \pm 0.0 b$ & $0.0 \pm 0.0^{b}$ & $0.0 \pm 0.0^{\mathrm{ab}}$ \\
\hline & 2.0 & $0.0 \pm 0.0^{b}$ & $0.0 \pm 0.0 b$ & $0.0 \pm 0.0^{\mathrm{b}}$ & $0.0 \pm 0.0^{\mathrm{ab}}$ \\
\hline Water & - & $3.8 \pm 1.79^{a}$ & $81.0 \pm 8.83^{a}$ & $8.11 \pm 0.89^{a}$ & $0.6 \pm 1.34^{\mathrm{a}}$ \\
\hline Glyphosate & 0.01 & $0.0 \pm 0.0^{\mathrm{b}}$ & $4.0 \pm 1.22^{\mathrm{b}}$ & $0.40 \pm 0.12^{b}$ & $0.4 \pm 0.55^{b}$ \\
\hline
\end{tabular}

(I)Means followed by the same letters indicate significant similarity by Dunnett's test $(p<0.05)$. Abbreviations: TREAT. Treatments; [ ]. Concentration; $\mathrm{NaOCl}$. sodium hypochlorite; GER. germination; GSI. germination speed index; RL. roo length; SL. Shoot length; IC. Interphase cells; PC. Prophase cells; MC. Metaphase cells; AC. Anaphase cells; TC. Telophase cells; DC. Dividing cells; MI. Mitotic index; CC. Chromosomal changes.

Regarding root and shoot length, the $\mathrm{NaOCl}$ concentration of $0.1 \%$ was similar to that of the glyphosate control, reducing root length by about half and tripling the shoot length relative to water (Table 2).

Glyphosate is a systemic herbicide, used as a positive control in phytotoxicity and cytotoxicity assays as it acts directly on the roots in a negative and prolonged manner, also presenting genotoxicity (Andrade et al., 2010; Rodrigues et al., 2013; Loren et al., 2019). When in contact with plant tissue, glyphosate enters the extracellular matrix and, upon reaching the cytoplasm, it is transported via phloem and distributed to the cellular tissues, causing lethal effects to the plant and also inhibiting the shikimate pathway in plants, consequently interfering with the biosynthesis of lignins and aromatic amino acids, such as tryptophan (Bochkov et al., 20I2). Toxicity tests of glyphosate formulations in Lenna minor evidence their inhibitory power on the synthesis of chlorophyll a and b, carotenoids, photosystem II activity, besides increasing the shikimic acid content by 15 to $21 \%$ with the application of glyphosate in low concentrations (Sikorski et al., 2019).

$\mathrm{NaOCl}$ delays the process of cell division, not being as harmful as glyphosate, whose mechanism of action in plants is related to the enzyme 5-enolpyruvalchiquimate-3- phosphate synthase (EPSPs), interfering with the synthesis of chorismate, a precursor of the tryptophan, tyrosine, and phenylalanine amino acids. In humans, it presents a growing tendency to correlate with various degenerative diseases, especially with increased autism in children (Nevison, 2014). Among these amino acids, the tryptophan produced in chloroplasts plays an important role, acting as an immediate precursor for the synthesis of IAA in plants. Auxin is the main regulator of organogenesis, acting on plant development and growth, regulating cell division, stretching, and differentiation, leading to the formation of shoot and root. Some tryptophan derivatives also act as precursors of IAA; however, they are considered dependent on tryptophan, such as indole pyruvic acid (AIP), indole acetaldoxime (IAOx), and indole acetamide (IAM) (Casanova-Sáez and Voß, 20I9).

However, with $\mathrm{NaOCl}$, there is a decrease in cell division and in the mitotic index, generating clastogenic (anaphasic bridge and chromosomal break) and aneugenic (loss and delay in chromosome formation) effects on cells (Figure 2), which explains the reduction in the germination, germination speed index, root and shoot length variables (Andrade et al., 20I0).

This fact explains the high number of abnormal seedlings with the species $D$. nigra in treatments with longer exposure to $\mathrm{NaOCl}$ since this product is difficult to remove and, despite the treatments being exposed to the same concentration, the prolonged contact of seeds to the product triggered high cellular changes, which reinforces the need for a more effective disinfestation protocol, although with less harmful effects to the explant, as observed in this study when exposing seeds of $D$. nigra to $\mathrm{NaOCl}$ for 14 min.

Experiment IV: Culture media and glutamine in the germination and initial growth of $D$. nigra.

Contamination, germination, GSI, MGT, normal and abnormal seedlings, non-developed seedlings, nongerminated seedlings, shoot length, number of lateral roots, shoot dry mass of seedlings, root dry mass of seedlings, and total dry mass of seedlings were not affected by the type of culture medium (Table 3). Rios et al. (20I5) observed a lower MGT (5 days), and according to these authors, the higher glucose content and the presence of maltose in mature dry seeds and the imbibition phases I and II may be associated with the longer time required for the preparation of seed germination in $D$. nigra.

The WPM medium provided a larger number of leaves and collar diameter of seedlings than the MS medium (Table 3). This last characteristic is indicative of rusticity, which is of great importance for the acclimatization of ex vitro seedlings. The MS medium provided a longer seedling root length in relation to the WPM medium. 
A

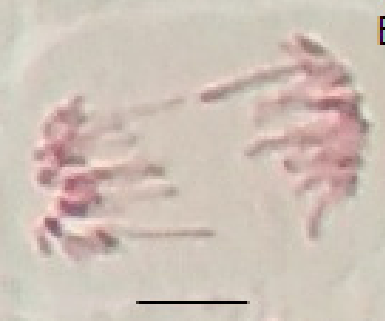

B

C

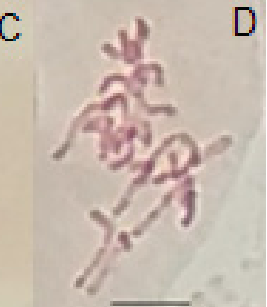

FIGURE 2 Characteristics evaluated in seeds and seedlings of $D$. nigra after different seed immersion times in $\mathrm{NaOCl}$. ** Significant at a $5 \%$ level of probability. Abbreviation: PMTE. Point of maximum technical efficiency.

TABLE 3 Culture media on in vitro growth of $D$. nigra

\begin{tabular}{ccccc}
\hline Culture media & CONT $(\%)$ & GER $(\%)$ & GSI & MGT (days) \\
\hline MS & $8.7 \pm 7.2^{\text {ns }}$ & $80.6 \pm 11.2^{\text {ns }}$ & $1.0 \pm 0.2^{\text {ns }}$ & $9.6 \pm 1.5^{\text {ns }}$ \\
WPM & $5.0 \pm 7.3$ & $86.2 \pm 10.9$ & $0.9 \pm 0.2$ & $10.3 \pm 1.3$ \\
\hline Culture media & NS $(\%)$ & AS $(\%)$ & NDS $(\%)$ & NGS $(\%)$ \\
\hline MS & $2.5 \pm 13.4^{\mathrm{ns}}$ & $3.1 \pm 4.8^{\mathrm{ns}}$ & $14.3 \pm 1.3^{\mathrm{ns}}$ & $20.0 \pm 10.3^{\mathrm{ns}}$ \\
WPM & $68.7 \pm 13.1$ & $7.5 \pm 10.0$ & $13.0 \pm 0.9$ & $14.3 \pm 12.1$ \\
\hline Culture media & $\mathrm{NL}$ & $\mathrm{CD}(\mathrm{mm})$ & $\mathrm{SL}(\mathrm{cm})$ & $\mathrm{RL}(\mathrm{cm})$ \\
\hline MS & $3.9 \pm 0.6^{*}$ & $1.5 \pm 0.1^{*}$ & $10.9 \pm 1.0 \mathrm{~ns}$ & $5.3 \pm 0.9 *$ \\
WPM & $4.5 \pm 0.9$ & $1.6 \pm 0.1$ & $10.2 \pm 1.4$ & $4.4 \pm 0.7$ \\
\hline Culture media & $\mathrm{NLR}$ & $\mathrm{DSMS}(\mathrm{mg})$ & $\mathrm{RDMS}(\mathrm{mg})$ & $\mathrm{TDMS}(\mathrm{mg})$ \\
\hline MS & $22.1 \pm 6.7^{\mathrm{ns}}$ & $37.1 \pm 3.4 \mathrm{~ns}$ & $20.4 \pm 5.4 \mathrm{~ns}$ & $57.6 \pm 6.9 \mathrm{~ns}$ \\
WPM & $20.6 \pm 5.2$ & $34.9 \pm 3.5$ & $21.2 \pm 5.0$ & $56.2 \pm 7.1$ \\
\hline
\end{tabular}

*Significant $(\mathrm{p}<0.05)$ and $n s$ Not significant by the $\mathrm{F}$ test. Abbreviations: MS. Murashige and Skoog; WPM. Lloyd and McCown; CONT. Contamination; GER. Germination; GSI. Germination speed index; MGT. Mean germination time; NS Normal seedlings; AS. Abnormal seedlings; NDS. Non-developed seedling; NGS. Non-germinated seeds; NL. Number of leaves; CD. Collar diameter; SL. Shoot length; RL. Root length; NLR. Number of lateral roots; DSMS. Dry shoot mass of seedlings; RDMS. Root dry mass of seedlings; TDMS. Total dry mass of seedlings.

The WPM medium is formulated for woody species; however, these species can adapt to in vitro cultivation using the MS medium. The woody plant medium (WPM) was suitable for all in vitro stages in Campomanesia xanthocarpa O. Berg (Myrtaceae), during the multiplication and rooting process, compared to the MS medium (Machado et al., 2020), which, according to these authors, is a culture medium with reduced salts and more suitable for rooting. The superiority of the WPM medium in the meristem culture of llex paraguariensis St.- Hill. can be attributed to the lower salt concentrations (especially nitrogen and potassium) (Tomasi et al., 20I8). For the in vitro establishment of sprouting apexes of Dipteryx alata Vog., the MS medium was considered to be more adequate compared to the WPM, providing seedlings with longer root length and higher leaf number, and an increase in dry mass was observed with the salt concentrations used $(25 ; 50 ; 75$, and $100 \%)$ for both in vitro culture media (Araruna et al., 2017).

The number of lateral roots produced in the MS medium decreases with increasing glutamine concentrations, and the opposite happens with the WPM medium (Figure 3). The gain in lateral roots in the WPM medium at the highest glutamine concentration $\left(0.75 \mathrm{mg} \mathrm{L}^{-1}\right)$ was eight roots. Root length, root dry mass of seedlings, and total dry mass of seedlings showed a linear growing behavior with increasing glutamine concentrations, for both culture media (Figure 3). Transgenic plants of Betula pubescens Ehrh., which are carriers of the GSI gene that encodes the cytosolic form of glutamine synthetase, have a high content of glutamine, as well as glutamic and aspartic acids, and rooted more rapidly compared to the control plants (Lebedv et al., 2018). These authors observed a positive correlation between the increase in the levels of auxin in these transgenic plants and an increase in the rooting rate.

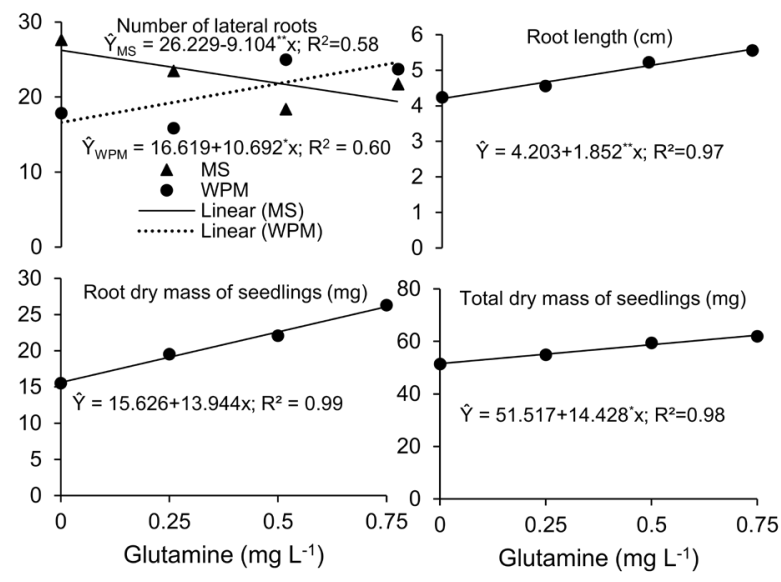

FIGURE 3 Characteristics evaluated of seedlings of $D$. nigra grown in different culture media (MS and WPM) and glutamine concentrations. ${ }^{*}$ Significant $(p<0.05)$.

The WPM medium has only $45 \%$ of the total ionic strength of the MS medium, and lower concentrations of nitrate $\left(\mathrm{NH}_{3}{ }^{-}\right)$(MS $40 \mu \mathrm{M}$; WPM $\left.9.7 \mu \mathrm{M}\right)$ and ammonium $\left(\mathrm{NH}_{4}^{+}\right)$(MS $20 \mu \mathrm{M}$; WPM $\left.4.9 \mu \mathrm{M}\right)$ (Phillips and Garda, 2019). Consequently, the WPM has a low total inorganic nitrogen concentration (14.7 $\mu \mathrm{M})$ compared to the MS $(60.0 \mu \mathrm{M})$ (Rocha et al., 2007). The growth of some plants may be impaired in media containing high concentrations of $\mathrm{NH}_{4}{ }^{+}$, reflecting toxicity induced by the accumulation of excess ammonium ions. Under normal circumstances, the toxic effect of ammonium is prevented by converting the ion into amino acids, in which L-glutamic acid is produced from glutamine by the action of the enzymes glutamine synthetase (GS) and glutamate synthetase (GOGAT) (George et al., 2008). 
The use of amino acids in in vitro crops has a positive influence in stimulating SE maturation, reducing embryonic abnormalities, and increasing plant conversion (L-glutamine) and at rooting as it provides organic nitrogen for the explant, a readily available form that acts on seedling growth and root system development (George et al., 2008; Rathore et al., 2012; Daniel et al., 20 I8; Garcia et al., 2019). Asparagine, cysteine, citrulline, and L-glutamine were tested for the in vitro rooting of CAB-6P (Prunus cerasus L.) and Gisela 6 (P. canescens $X$ $P$. cerasus) cherry rootstocks, using four concentrations ( 0 ; 0.5 ; I and $2 \mathrm{mg} \mathrm{L-I})$ combined with $2 \mathrm{mg} \mathrm{L-I}$ of indole3-butyric acid. CAB-6P presented a higher number of roots compared to Gisela 6 , highlighting the cysteine and L-glutamine amino acids at a concentration of $0.5 \mathrm{mg} \mathrm{L}-\mathrm{I}$ (I4.18 and II .08 respectively) (Sarropoulou et al., 20 I6).

\section{CONCLUSIONS}

I and II. $\mathrm{NaOCl}(2.5 \%)$ for 14 min is recommended for the disinfestation of seeds of Dalbergia nigra. III. $\mathrm{NaOCl}$ has a high phytotoxic, cytotoxic, and genotoxic effect, and its mechanism of action in the Lactuca sativa cell cycle is clastogenic and aneugenic, suggesting that it may influence the formation of abnormal seedlings of Dalbergia nigra. IV. The WPM medium and its supplementation with glutamine ( $\left.0.75 \mathrm{mg} . \mathrm{L}^{-1}\right)$ is recommended.

\section{ACKNOWLEDGEMENTS}

The authors thank FAPES/SEAG Notice No. $06 / 2015$ for the research funding, and CNPq for granting the research scholarship.

\section{REFERENCES}

ABDUL-BAKI, A. A. Pitfalls in using sodium hypochlorite as a seed disinfectant in I4C incorporation studies. Plant Physiology, v. 53, p. 768-77I, 1974.

ANDRADE, L. F; DAVIDE, L. C.; GEDRAITE, L. S. The effect of cyanide compounds, fluorides, aluminum, and inorganic oxides present in spent pot liner on germination and root tip cells of Lactuca sativa. Ecotoxicology and Environmental Safety, v. 73, p. 626-63I, 2010.

ARARUNA, E. C.; RIBEIRO-OLIVEIRA, J. P.; PEREIRA, V. J.; ASMAR, S. A.; MELO, B. Salt concentrations in culture media for the development of Dipteryx alata in vitro. Pesquisa Agropecuária Brasileira, v. 52, n. 12, p. $1295-$ 1300, 2017.

BEVILACQUA, C. B.; REINIGER, L. R. S.; GOLLE, D. P.; ROSA, F. C. Desinfestação superficial, germinação e regeneração in vitro a partir de sementes de calêndula. Ciência Rural, v. 4 I, p. 76I-766, 201 I.
BOCHKOV, D. V.; SYSOLYATIN, S. V.; KALASHNIKOV, A. I.; SURMACHEVA, I. A. Shikimic acid: review of its analytical, isolation, and purification techniques from plant and microbial sources. Chemistry and Biology, v. 5, p. 5-17, 2012

BRASIL. Ministério do Meio Ambiente. Portaria n. ${ }^{\circ} 443$, de 14 de dezembro de 2014. Lista Nacional Oficial de Espécies da Flora Ameaçadas de Extinção. Diário Oficial da União, Brasília, 14 dez. 2014. Seção 0I, p. I2I.

BRASIL. Ministério da Agricultura, Pecuária e Abastecimento. Regras para análise de sementes. MAPA/DAS/ACS. 395p. 2009.

CASANOVA-SÁEZ, R.; VOß, U. Auxin metabolism controls developmental decisions in land plants. Trends in Plant Science, v. 24, p. 74I-754, 2019.

CRUZ, C. D. Genes Software - extended and integrated with the R, Matlab and Selegen. Acta Scientiarum. Agronomy, v. 38, p. $547-552,2016$.

DANIEL, M. A.; DAVID, R. H. A.; CAESAR, S. A.; RAMAKRISHNAN, V.; DURAIPANDIYAN, V.; IGNACIMUTHU, S.; AL-DABI, N. A. Effect of L-glutamine and casein hydrolysate in the development of somatic embryos from cotyledonary leaf explants in okra (Abelmoschus esculentus L. monech). South African Journal of Botany, v. II4, p. 223-23I, 2018.

DONINI, L. P.; FERREIRA-MOURA, I.; GUISSO, A. P.; SOUZA, J. A.; VIÉGAS, J. Preparo de lâminas foliares de aráceas ornamentais: desinfestação com diferentes concentrações de hipoclorito de sódio. Arquivos do Instituto Biológico, v. 72, p. 517-522, 2005.

FRANCESCHI, C. R.; SMIDT, E. C.; VIEIRA, L. N.; RIBAS, L. L. Storage and in vitro germination of orchids (Orchidaceae) seeds from Atlantic Forest-Brazil. Anais da Academia Brasileira de Ciências, v. 91, n. 3, p. I-II, 2019.

GAMAGE, D.; THOMPSON, M.; SUTHERLAND, M.; HIROTSU, N.; MAKINO, A.; SENEWEERA, S. New sights into the cellular mechanisms of plant growth at elevated atmospheric carbon dioxide concentrations. Plant, Cell \& Environment, v. 4I, p. I233-1246, 2018.

GARCIA, C.; ALMEIDA, A-A. F.; COSTA, M.; BRITTO, D.; VALLE, R.; ROYAERT, S.; MARELLI, J-P. Abnormalities in somatic embryogenesis caused by 2,4-D: an overview. Plant Cell, Tissue and Organ Culture, v. 137, p. 193- 212, 2019.

GEORGE, E. F.; HALL, M. A.; DE KLERK, G. J. Plant propagation by tissue culture. 3. ed. Dordrecht: Springer, 2008. 50 I p.

GUERRA, M.; SOUZA, M. J. Como observar cromossomos: um guia de técnicas em citogenética vegetal, animal e humana. Ribeirão Preto: Ed. FUNPEC, 2002. I 3 I p. 
KARMAKAR, R.; BINDIYA, S.; HARIPRASAD, P. Convergent evolution in bacteria from multiple origins under antibiotic and heavy metal stress, and endophytic conditions of host plant. Science of the Total Environment, v. 650, p. 858-867, 2019.

LABOURIAU, L. G. A germinação das sementes. Washington: OEA. 174p. 1983.

LEBEDEV, V. G.; KOROBOVA, A. V.; SHENDEL, G. V.; KUDOYAROVA, G. R.; SHESTIBRATOV, K. A. Effect of glutamine synthetase gene overexpression in birch (Betula pubescens) plants on auxin content and rooting in vitro. Biochemistry, Biophysics, and Molecular Biology, v. 143, p. I43-145, 2018.

LEITE, F. A. B.; BRANDÃO, R. L.; BUZATTI, R. S. O.; LEMOSFILHO, J. P.; LOVATO, M. B. Fine-scale genetic structure of the threatened rosewood Dalbergia nigra from the Atlantic Forest: Comparing saplings versus adults and small fragment versus continuous forest. Tree Genetics \& Genomes, v. 10, p. 307-316, 2014.

LLOYD, G.; McCOWN, B. Commercially feasible micropropagation of mountain laurel (Kalmia latifolia) by use of shoot-tip culture. Proceedings of the International Plant Propagation Society, v. 30, p. 42 I-427, 1980.

LOREN, C. V.; SANTOS, E. S.; BERNARDES, C. O.; FERREIRA, M. F. S.; FERREIRA, A.; TULER, A. C.; CARVALHO, J. A. M.; PINHEIRO, P. F; PRAÇA-FONTES, M. M. Phytochemical analysis and effect of the essential oil of Psidium L. species on the initial development and mitotic activity of plants. Environmental Science and Pollution Research, v. 26, p. 26216-26228, 2019.

LORENZI, H. Árvores brasileiras: manual de identificação e cultivo de plantas arbóreas nativas do Brasil. 7. ed. São Paulo: Instituto Plantarum, 2016. v. I. 384 p.

MACHADO, J. S.; DEGENHARDT, J.; MAIA, F. R.; QUOIRIN, M. Micropropagation of Campomanesia xanthocarpa O. Berg (Myrtaceae), a medicinal tree from the Brazilian Atlantic Forest. Trees, v. I, p. I-9, 2020.

MAGUIRE, J. D. Speeds of germination-aid selection and evaluation for seedling emergence and vigor. Crop Science, v. 2, n. 2, p. 176-177, 1962.

MENDY, T. K.; MISRAN, A.; MAHMUD, T. M. M.; ISMAIL, S. I. Antifungal properties of Aloe vera through in vitro and in vivo screening against postharvest pathogens of papaya fruit. Scientia Horticulturae, v. 257, p. I08767, 2019.

MONFORT, L. E. F; PINTO, J. E. B. P.; BERTOLUCCI, S. K. V.; ROSSI, Z. T. T.; LIMA, A. F.; SILVA, S. T.; SILVA, G. M. Micropropagação e germinação de sementes in vitro de atroveran. Revista Ceres, v. 62, n. 2, p. 215-223, 2015.

MURASHIGE, T.; SKOOG, F. A revised medium for rapid growth and bioassays with tobacco tissue cultures. Physiologia Plantarum, v. I5, p. 473-497, 1962.
NEVISON, C. D. A comparison of temporal trends in United States autism prevalence to trends in suspected environmental factors. Environmental Health, v. I3, n. 73, p. I-16, 2014.

PHILLIPS, G. C.; GARDA, M. Plant tissue culture media and practices: an overview. In vitro Cellular \& Developmental Biology - Plant, v. 55, p. 242-257, 2019.

RATHORE, J. S.; RAI, M. K.; SHEKHAWAT, N. S. Induction of somatic embryogenesis in gum arabic tree [Acacia senegal (L.) Willd.]. Physiology and Molecular Biology of Plants, v. I8, p. 387-392, 2012.

RIOS, A. P. S.; ARAGÃO, V. P. M.; PASSAMANI, L. Z.; MACEDO, A. F.; FULGÊNCIO, L. A. P.; FLOH, E. I. S.; BARROSO, D. G.; SILVEIRA, V.; SANTA-CATARINA, C. High level of sucrose, spermine and spermidine are related with the early germination in Plathymenia foliolosa compared to Dalbergia nigra. Theoretical and Experimental Plant Physiology, v. 27, p. 237-249, 2015.

ROCHA, S. C.; QUORIM, M.; RIBAS, L. L. F; KOEHLER, H. S. Micropropagation of Cabralea canjerana. Revista Árvore, v. 3I, n. I, p. 43-50, 2007.

RODRIGUES, L. C. A.; BARBOSA, S.; PAZIN, M.; MASELLI, B. S.; BEIJO, L. A.; KUMMROW, F. Fitotoxicidade e citogenotoxicidade da água e sedimento de córrego urbano em bioensaio com Lactuca sativa. Revista Brasileira de Engenharia Agrícola e Ambiental, v. 17, n. 10, p. 1099I 108, 2013.

SANTOS, J.; PINHEIRO, M. V. M.; FONTANA, D. C.; SCHMIDT, D.; PRETTO, M. M. Estabelecimento in vitro de oliveira 'Arbequina' e 'Koroneiki'. Ciência Florestal, v. 29, n. 2, p. 508-518, 2019.

SARMAST, M. K. In vitro propagation of conifers using mature shoots. Journal of Forestry Research, v. 29, n. 3, p. 565$574,2018$.

SARROPOULOU, V.; CHATZISSAWIDIS, C.; DIMASSITHERIOU, K.; THERIOS, I. Effect of asparagine, cysteine, citrulline, and glutamine on in vitro rooting and biochemical constituents in cherry rootstocks. Biologia Plantarum, v. 60 , n. I, p. I-12, 2016.

SIKORSKI, L.; BACIAK, M.; BEŚS, A.; ADOMAS, B. The effects of glyphosate-based herbicide formulations on Lemna minor, a non-target species. Aquatic Toxicology, v. 209, p. $70-80,2019$.

SILVA, E. R.; SIMÕES, I. M.; BAPTISTA, J. O.; BIGHI, K. N.; FONTES, M. M. P.; SCHMILDT, E. R.; LOPES, J. C.; CALDEIRA, M. V. W.; ALEXANDRE, R. S. In vitro germination of Melanoxylon brauna Schott. and evaluation of the toxicity of disinfecting agents in the Lactuca sativa $L$. model plant. Cerne, v. 25, n. 4, p. 375-385, 2019.

TOMASI, J. C.; DEGENHARDT-GOLDBACH, J.; GRUNENNVALDT, R. L.; SANTOS, G. D.; VICENTE, V. A.; FRANCISCON, L.; BONA, C.; QUOIRIN, M. In vitro establishment of shoot meristems of llex paraguariensis and identification of endophytic bacteria. Journal of Forestry Research, v. 30, p. 1765-1777, 2018. 